\title{
CAPITAL MARKET UNION: CREATING NEW OPPORTUNITIES TO SOCIAL ENTERPRISES
}

\begin{abstract}
The objective of the paper is to examine the studied enterprises in terms of use of the planned Capital Market Union changes, mainly an access to equity and debt instruments. Existing gap in the capital available to the social enterprises (SE) points to significant constraints in banking industry's financing ability, and the author explore the question of what potential opportunities for the development of financial instruments supporting social enterprises sectors can be created in the context of the establishment of the CMU. In the current discussion about CMU much space has been devoted to its impact on the SME sector. However, It doesn't take up the theoretical review of the likely consequences of the project for social enterprises. The analysis of available documents indicate that financing opportunities in the social enterprise sector in the result of CMU project will depend on the scale and scope of the social impact of social enterprises. The main implications of the paper contribute towards understanding how $\mathrm{CMU}$ project can translate into diversification and greater availability of financial sources supporting social enterprises, more effective SE funding policy design and more accurate implications forecasting for creating capital market dedicated for SE. Managers of social entrepreneurs will find the results useful for developing their business strategies, being more aware of the possible implications of CMU project.
\end{abstract}

Keywords: capital market union; social entrepreneurs, capital sourcing, financial instruments, social investors, social capital market.

\section{INTRODUCTION}

Existing gap in the capital available to the social enterprises belonging to the small business sector points to significant constraints in banking industry's financing ability. Sustainable financing currently accessible through ethical banks, whose operation is mainly dedicated to social entrepreneurships is very limited to institutions, which makes them unable to sufficiently satisfy growing capital needs of the said social enterprises. Diversification in capital sourcing through non-bank financing could partially compensate for the negative effects of the limited capital access by the small business ventures.

Due to very specific operational functionality of social entrepreneurships, where excess revenue is not considered as an investable financial surplus, but means to accomplish social mission of the firm, a systemic solution seems as a more appropriate approach also on the

\footnotetext{
${ }^{1}$ Paweł Mikołajczak, DSc, PhD, Department of Money and Banking, Poznań University of Economics and Business, Aleje Niepodległości 10, 61-875 Poznań, Poland, tel.: +48 618543372 , e-mail: pawel.mikolajczak@ue.poznan.pl.

Dr hab. Paweł Mikołajczak, Katedra Pieniądza i Bankowości, Uniwersytet Ekonomiczny w Poznaniu, Aleje Niepodległości 10, 61-875 Poznań, Poland, tel.: +48 618543372 e-mail: pawel. mikolajczak@ue.poznan.pl.
} 
institutional level. A viable answer to these challenges might be the concept of the EU's capital markets union, whose main goals are the economic growth stimulation, rise in investments and unemployment reduction, as well as expansion of innovation and competition in Europe's markets. In the context of these observations, objective of the paper can be set to examine the studied enterprises in terms of use of the planned CMU changes, mainly access to equity and debt instruments. Adopted thesis states: application of varied forms of financing through capital market instruments in social entrepreneurship sector via the CMU methodology will largely depend on the level of development and scope of operation of the said subjects.

The paper is of conceptual nature. The paper seeks to assess the specific areas of the CMU initiative: corporate bonds, venture capital, and social financing as a potential increase in access to capital for the social enterprises with varied size and operational focus. It does so by examining the existing academic literature, policy document, proposals for a regulation of the European Parliament and of the Council, European Commission communications, EU law and related documents, Official Journal of the EU. In the current discussion about CMU much space has been devoted to its impact on the SME sector. However, It doesn't take up the theoretical review of the likely consequences of the project for social enterprises. The paper reflects on potential opportunities for the development of financial instruments supporting social enterprise sectors in the context of the establishment of the CMU. Author selected also these financial instruments that are adequate for financing the social enterprises. An attempt was made to assign these instruments to certain types of social enterprises due to the scale and scope of their activities. The framework is used to summarize the scope of available instruments to finance social enterprises indicating their potential for wider use through the introduction of a unified capital market in the European Union.

\section{RATIONALE FOR CREATION OF THE CAPITAL MARKET UNION}

Initially the concept of the uniform capital market was introduced on July $15^{\text {th }}, 2014$ by European Commission's Chairman - elect, Jean-Claude Juncker. It is based on a belief that there's a need for creation of an alternative source of financing of the economic growth in UE, which translates into a strong capital market. As a consequences of the 2007-2008 financial crises, Europe experienced decline of the economic activity, recession and stagnation in its economies, this causing serious difficulties within the region's financial institutions. As a result, emerged a necessity of securing Europe's and the UE's financial system by creating the European System of Financial Supervision, European Systematic Risk Board and the implementation of bank union methodology in the countries within the euro zone ${ }^{2}$. The financial crisis has also highlighted the disadvantages of excessive reliance on a model focused on bank loans and pointed to the need of developing reliable sources of non-banking credit, such as equity and bond markets, securitization, venture capital, and crowdfunding ${ }^{3}$.

\footnotetext{
${ }^{2}$ M. Marcinkowska, P. Wdowiński, S. Flejterski, S. Bukowski, M. Zygierewicz, Wptyw regulacji sektora bankowego na wzrost gospodarczy-wnioski dla Polski, Inst. Ekonomiczny, 2014, p. 22.

${ }^{3}$ M. Draghi, Keynote speech at the Eurofi Financial Forum. Frankfurt am Main: European Central Bank Directorate General Communication, 2014.
} 
European financial model which assumes the dominant role of commercial banks in the process of collection and allocation of capital between the entities of the economic system associated with strong regulation in the area of capital, supervision and banking risk arising as a consequence of the financial crisis, have reduced banks' willingness to jeopardize their operation in relation to lending, at the same time pointing out that the opportunity to stimulate economic growth in the EU by the banks will be extremely limited ${ }^{4}$.

The program including a full implementation of CMU, in a nutshell, should cover three areas. The first one relates to the supply side of the market and includes the issuance of capital market instruments, containing the use of a greater range of high-quality securitization, public issue and private placement of shares (IPO, Initial Public Offering, SPO, Secondary Public Offering, private placement), corporate and banks bonds, as well crowdfunding and direct peer-to-peer ${ }^{5}$.

The abovementioned instruments are meant to increase access of SMEs to capital, which usually are the ones who mostly feel the effects of changes in the banking sector. Social enterprises are in a particularly difficult situation. As it has been repeatedly pointed out, the peculiarities of these types of businesses, their small number and high operating cost result in lack of interest and consequently shape the adverse credit policy from the banking sector. In relation to the size of the social enterprise sector, financial institutions lack an appropriate offer of products, procedures and adequately qualified staff to meet this sector's needs. In turn, the relatively weak financial condition of the majority of social enterprises and the absence or low value of assets held, heightens credit risk, as well as the inability and cost of acquiring the capital. The main importance in the context of the possibility of using debt instruments are the goals of the social enterprises expressed in the primacy of the social over the economic effects, which greatly reduces the possibility of raising capital through the banking sector 6 .

A number of authors have focused on testing the determinants and effects of bank lending constraints on firms since the onset of the crisis ${ }^{7}$. However, less research has been undertaken on the perspective of the creation of the CMU to the possibility of financing SMEs'. Particularly difficult to assess is the role of CMU on alternative sources of finance of social entrepreneurs.

\section{SOCIAL ENTERPRISES - THE SCALE AND SCOPE OF ACTIVITIES}

The multidimensional nature of social enterprises highlights a variety of motives, types of projects and strategies designed to increase social welfare. This means that it's necessary to separate the different types of social entrepreneurs solving specific social problems with

\footnotetext{
${ }^{4}$ M. Hamunen, The Impact of a Capital Markets Union in Europe, „CFA Institute Magazine” 2015, 26/5, p. 51.

${ }^{5}$ Green Paper, Building a Capital Markets Union, Brussels, COM(2015), 63 final, no. 7, 2015.

${ }^{6} \mathrm{P}$. Mikołajczak, Struktura finansowania inwestycji matych $i$ średnich przedsiębiorstw refundowanych z funduszy europejskich w Wielkopolsce, „Humanities and Social Sciences” 2014, 3, p. 161-172.

7 A. Popov, G. Udell, Cross-border banking, credit access, and the financial crisis, „Journal of International Economics" 2012, 87/1, p. 147-161.
} 
the available resources, primarily financial ${ }^{8}$. Among those, one should distinguish entities that are able to mobilize the forces and capabilities to solve social problems in the entire world. Using the necessary ability of social activity to inspire efforts on the part of commercial and non-commercial partners, donors, volunteers and staff by building relationships, one can also distinguish social enterprises, which involve various government organizations focused on solving specific problems within the existing institutional order. On the other hand, some entrepreneurs primarily direct their actions on issues of strictly local scale. Identifying the similarities and differences between the organizations involved in social entrepreneurship and necessary financial instrument that will drive their development, could provide an important indicator on how to pinpoint the potential beneficiaries of European capital markets union among social enterprises.

The first type of the discussed entities includes social enterprises, which play a key role on a local scale. Their knowledge about the immediate environment is very important in the entrepreneurial processes, because it allows them to often identify social problems unrecognizable to others. They make decisions in an intuitive way based on data that is usually difficult to codify or information provided by various organizations ${ }^{9}$. These entities, with access to very limited means, are able to create very innovative solutions. The competitive advantage of this type of businesses results primarily from a thorough knowledge of the local environmental conditions, as well as locally available resources. Although the scope and extent of their impact is fairly small, those skills allow them to meet the challenges of various local communities by increasing their welfare. The implementation of projects, in the above discussed type of entities, does not require any particular, specialized external resources, what clearly distinguishes them from other social enterprises that are often dependent on the various providers of capital. Their autonomy and independence from the various capital providers, limits attempts to impose any agendas and reduces the risk of moving away from the original social mission ${ }^{10}$. In addition, social enterprises operating locally are able to respond quickly to changing conditions. The undoubted weaknesses of their business, however, is a kind of dependence on modest, but readily available financial resources, limited expertise, improvisation instead of formal planning, which sometimes prevent them to more effectively meet larger social needs, and extending the scope of their impact ${ }^{11}$.

Another type of social enterprise has the potential to achieve competitive advantages by not solely possessing a specific knowledge on the conditions forming the local environment, but rather their openness and a kind of alertness to the opportunities that arise from the development of products, goods and services that they offer. For this reason, these companies have the ability to design and introduce significant changes in the existing

8 P. Mikołajczak, The Importance of Funding Sources to the Scale of Activity of Social Enterprises, „Finanse, Rynki Finansowe, Ubezpieczenia” 2017, 4/88, p. 135-144.

9 K.R. Conner, C.K. Prahalad, A resource-based theory of the firm: Knowledge versus opportunism, „Organization Science” 1996, 7/5, p. 477-501.

${ }^{10}$ G. Vacekova, V. Valentinov, J. Nemec, Rethinking non-profit commercialization: the case of the Czech Republic, Voluntas, "International Journal of Voluntary and Nonprofit Organizations" 2017, 28/5, p. 2103-2123.

11 P. Mikołajczak, W. Czternasty, Social enterprises versus globalisation, "INTERCATHEDRA" 2015, 31/2, p. 2103-2123. 
system $^{12}$. Introducing innovation for a wide range of social impact, these companies are able to effectively and efficiently operate, satisfying social needs of recipients that have not yet been fulfilled by the competition. The needs that are identified and implemented by such enterprises assist creation of social wealth, at the same time filling a gap in the area that is not at all or improperly developed by existing institutions, governmental or nongovernmental and commercially operating entities ${ }^{13}$. The necessity for action of these social enterprises therefore stems from the lack of interest in social problems of individuals targeted solely to make a profit, as well as impotence or lack of skills of non-profit or government organizations that do not have the ability to create social innovation ${ }^{14}$. The motivation and the vision for operating of this type of social enterprise enables them to act based on planning, and even predicting future events leading to solving important social problems on a larger scale. Their actions may have regional or national character. Some of them even have the potential of international impact ${ }^{15}$. In comparison to the locally operating social enterprises that often operate on the principle of improvisation, this type of entities to meet the growing social needs, approach it by tackling the broader issues through planning and development of formalized or structured, scalable solutions, or ones that could be transferred to a new and wide variety of social contexts ${ }^{16}$.

The above advantages of the companies in question do not stem from the knowledge of local conditions, but from their unique ability to detect and implement these opportunities that generate social wealth through the creation and configuration of processes aimed at providing certain goods and services. They are thus the subject of interest from outside investors. The innovative nature of the services they provide ensures this type of business can benefit from a variety of sources of financing, and in consequence, ability to obtain considerable financial independence.

Sometimes important social needs are not susceptible to solutions within the framework of existing institutions, approaches that are inadequate or ineffective in solving social problems. In turn, a powerful government or business elites can halt efforts to bring about reform ${ }^{17}$. Entrepreneurs who are willing to act to solve these complex problems can be qualified as the next group. They differ substantially from the other two types of businesses, particularly in their ability to implement system changes. These entities manifest the necessity to totally reconstruct outdated structures and processes to ones that are more

12 A. Fowler, NGDOs as a moment in history: beyond aid to social entrepreneurship or civic innovation? „Third World Quarterly” 2000, 21/4, p. 637-654.

${ }^{13}$ S.A. Zahara, E. Gedajlovic, D.O. Neubaum, J.M. Shulman, A typology of social entrepreneurs: Motives, search processes and ethical challenges, ,Journal of Business Venturing” 2009, 24/5, p. 519-532.

14 J. Thompson, G. Alvy, A. Lees, Social entrepreneurship-a new look at the people and the potential, „Management Decision” 2000, 38/5, p. 328-338.

15 D.W. Brinkerhoff, J.M. Brinkerhoff, Partnerships between international donors and non-governmental development organizations: Opportunities and constraints, "International Review of Administrative Sciences" 2004, 70/2, p. 253-270.

${ }^{16}$ B. Battle Anderson, J.G. Dees, Rhetoric, Reality, and Research: Building a Solid Foundation for the Practice of Social Entrepreneurship [In:] Social Entrepreneurship: New Models of Sustainable Social Change, ed. A. Nicholls, Oxford University Press, 2006, p. 144-168.

${ }_{17}$ M. Carney, E. Gedajlovic, The co-evolution of institutional environments and organizational strategies: The rise of family business groups in the ASEAN region, „Organization Studies” 2002, 23/1, p. 1-29. 
Table 1. Types of social entrepreneurs

\begin{tabular}{|c|c|c|c|}
\hline $\begin{array}{l}\text { Type of social } \\
\text { entrepreneurs }\end{array}$ & Type I & Type II & Type III \\
\hline $\begin{array}{c}\text { Scale and scope } \\
\text { of activity }\end{array}$ & $\begin{array}{l}\text { Small scale of impact, } \\
\text { local scope of operation. }\end{array}$ & $\begin{array}{l}\text { Small to large-scale } \\
\text { impact, local to interna- } \\
\text { tional scope of operation. }\end{array}$ & $\begin{array}{l}\text { Very large scale of impact, } \\
\text { national to international } \\
\text { scope of operation. }\end{array}$ \\
\hline Goals & $\begin{array}{l}\text { Derived from the know- } \\
\text { ledge of often scattered or } \\
\text { misunderstood and } \\
\text { difficult to grasp local } \\
\text { social needs and the } \\
\text { ability and the will to } \\
\text { satisfy them. }\end{array}$ & $\begin{array}{l}\text { Derived from the lack of } \\
\text { acceptance of the existing } \\
\text { regulatory and political } \\
\text { solutions, as well as the } \\
\text { inefficiency and/or lack } \\
\text { of will of existing } \\
\text { governments, or business } \\
\text { elite to solve problems } \\
\text { of society in an effective } \\
\text { manner. Striving to make } \\
\text { changes within the } \\
\text { existing systems. }\end{array}$ & $\begin{array}{l}\text { Some important social } \\
\text { needs are not susceptible } \\
\text { to solution within the } \\
\text { framework of existing } \\
\text { institutions. These entities } \\
\text { may be insufficient, or } \\
\text { governments and business } \\
\text { elites can stall efforts to } \\
\text { bring about reform. } \\
\text { Build a durable structure } \\
\text { that will challenge the } \\
\text { existing order to solve } \\
\text { social problems and } \\
\text { attempt to significantly } \\
\text { replace the current } \\
\text { systems. }\end{array}$ \\
\hline $\begin{array}{l}\text { Financial and } \\
\text { non-financial } \\
\text { resources }\end{array}$ & $\begin{array}{l}\text { Require small resources to } \\
\text { identify and resolve local } \\
\text { social problems. } \\
\text { Possess necessary } \\
\text { knowledge, experience } \\
\text { and skills to meet local } \\
\text { social needs imperceptible } \\
\text { to others. Location allows } \\
\text { for a quick response. } \\
\text { Financial ability is often } \\
\text { determined by } \\
\text { accumulated member } \\
\text { contributions, public } \\
\text { grants and private donors. } \\
\text { Limited extent of ethical } \\
\text { financing. }\end{array}$ & $\begin{array}{l}\text { Possess the resources } \\
\text { necessary to address the } \\
\text { broader social problems } \\
\text { through planning and } \\
\text { development of formalized } \\
\text { or structured, and scalable } \\
\text { solutions to meet the } \\
\text { growing needs or that they } \\
\text { could be transferred to } \\
\text { new and varied social } \\
\text { contexts. Their capabilities } \\
\text { stem from a unique ability } \\
\text { to identify and implement } \\
\text { solutions that generate } \\
\text { social wealth through the } \\
\text { process creation or } \\
\text { configuration, providing } \\
\text { innovative goods and } \\
\text { services. Source of } \\
\text { financing is obtained } \\
\text { mainly through external } \\
\text { investors and ethical } \\
\text { banks. }\end{array}$ & $\begin{array}{l}\text { Can have a profound } \\
\text { impact on society and be } \\
\text { the leading engine of } \\
\text { social reforms. Have the } \\
\text { potential and resources to } \\
\text { break the barriers in } \\
\text { dealing with national, } \\
\text { international or global } \\
\text { social problems. } \\
\text { Significant non-financial } \\
\text { resources and big } \\
\text { ambitions can be used to } \\
\text { gain support in fulfilling } \\
\text { their social tasks. The } \\
\text { ability to act is based on } \\
\text { the skill to the gain } \\
\text { sufficient political and } \\
\text { financial capital } \\
\text { supporting their actions. } \\
\text { Funds are collected from } \\
\text { external investors (capital } \\
\text { markets, venture capital) } \\
\text { but have limited interest } \\
\text { from commercial banking } \\
\text { sector. Characterized by } \\
\text { high financial } \\
\text { independence. }\end{array}$ \\
\hline
\end{tabular}

Source: own elaboration. 
efficient and better adjusted to modern socio-economic trends. The problems that are confronted by these types of business are however on a national, international or global scale. The revolutionary and ideological nature of the reforms introduced by them may even pose a threat to the interests of the various types of institutions and sometimes may be seen as subversive. The large scale and scope of their ambitions, as well as legitimacy deficits, however, can be used to obtain broad support in order to fulfill their public goals. As a result, the possibility for action of this type of entity is based on their ability to acquire political capital, as well as the ability to raise funds from external investors for the implementation of its social mission ${ }^{18}$.

\section{THE OBJECTIVES AND INSTRUMENTS OF THE UNION CAPITAL MARKETS - SOCIAL ENTERPRISES FINANCING PROSPECTS ASSESSMENT}

Strongly integrated capital markets allow free movement of capital between countries. This gives companies easier access to foreign capital, while allowing investors to diversify their portfolios. Regardless of the more than fifty years of integration in other areas, the market entities executing capital transactions remain surprisingly fragmented in the EU. Total number of sixteen stock exchanges in the EU seems to be too high, especially when compared to the US, which has only two national stock exchanges ${ }^{19}$. CMU short-term objectives, as previously mentioned are to increase the efficiency of capital markets by matching supply and demand as well as diversification, improvement of their efficiency via increase in competition, lowering costs and extending the availability of equity instruments resulting from removing the traditional barriers between member countries.

Medium and long term goals and the priorities of the CMU is to improve efficiency of management within the in the European Union through diversification of supply of capital from individual and institutional investors, removing barriers for a sustainable infrastructure of the market, legal norms, and access to capital of all companies in Europe in terms of variety and lower cost of financing instruments ${ }^{20}$.

\section{Social Corporate Bonds}

In reference to the potential opportunities for the development of financial instruments supporting social enterprise sectors in the context of the establishment of the CMU, it is worth noting proposed changes in corporate bonds among other things. In the concept of the capital markets union, arises a possibility of harmonization, at EU level, of the rules on obtaining and enforcing writs of execution relating to claims arising from covered bonds introduced to organized trading system in case of delayed payment of benefits from such bonds. There's also an indication of the need to unify regulations at the national level to allow bond protection from bankruptcy filings and effective enforcement pass-through mechanism, at the same time underlining the legitimacy of the implementation of the

\footnotetext{
18 A. Groot, B. Dankbaar, Does Social Innovation Require Social Entrepreneurship? "Technology Innovation Management Review" 2014, 4/12, p. 17-23.

19 O. Kaya, Capital Markets Union: Am ambitious goal but few quick wins, EU Monitor, Deutsche Bank Research, Frankfurt am Main, 2015.

${ }^{20}$ M. Abascal, T. Alonso, L. Pacheco, First step towards a Capital Market Union, Regulation Flash, 19 February 2015, BBVA Research, 2015.
} 
relevant procedural changes that will shorten the time required for cross-border collateral enforcement. In addition, there's a considerable demand for desirable legislative changes introducing harmonized rules for resolving conflicts of law in all aspects of storage, purchase and sale of securities. It is recognized in particular that they should increase transparency and certainty in relation to the ownership of securities as collateral security in the whole securities chain, including in the context of cross-border and in repeated use. It is also contemplated to introduce uniform regulations for the implementation of mortgages and deposits within the EU, mainly with regard to the possibility of realization of security by the secured creditor, and that only the enforcement costs could be met before the secured debt. The implementation of such actions could result in greater investor interest in buying bonds, including those issued by the social enterprises possessing securities regardless of the scale and scope of their activities. Their profitability usually is less than those of the traditional companies, but the evidence found in practical experience of the loan funds or ethical banks indicates the reliability and timeliness of debt repayment, which gives them attractive qualities. In addition, issuance of social bonds (SIBs) covered by the national treasury, initiated by public administration or local government units, entrusting the solution of an earlier identified social problem, can contribute to increased demand for debt securities of domestic and foreign institutional investors looking to expand their social responsibility, banks, individual investors and other entities. The possibility of issuing social corporate bonds rather be attributed to social enterprises with a stronger market position and considerable potential and scale of the impact ${ }^{21}$.

\section{High Quality Securitization}

Similar reflections arise in relation to the CMU key project - "high quality securitization", the result of which would primarily be to increase the level of transparency, integrity and availability of critical information for investors. Securitization in the concept of building the capital markets union should facilitate easier issuance of securities products and to enable institutional investors to conduct due diligence with respect to the products that meet their needs in terms of asset diversification, return on investment and its duration (EU Commission 2015) ${ }^{22}$.

An extremely important addition to all other entities involved in the securitization process would be the rating agencies that determine the degree of the quality of the securitized assets. Their assessment is most important when estimating the investors' investment risk and translates directly to profitability of the purchased $\mathrm{ABS}^{23}$. In the concept of the CMU mentioned above project - formation of specialized credit rating agencies in the local SME sector may directly translate into increased use of securitization by the economically strong social enterprises sector in Europe, where their assets are of interested to the so-called "patient capital" 24 . Currently, this form of obtaining capital is primarily

${ }^{21}$ P. Mikołajczak, Źródta i instrumenty..., p. 356.

22 EU Commission, Building a Capital Markets Union, "Green Paper” 52015DC0063 (2015).

${ }^{23}$ N. Anderson, M. Brooke, M. Hume, M. Kürtösiova, A European Capital Markets Union: implications for growth and stability, "Bank of England Financial Stability Paper" 2015, 33, p. 3-23.

24 A. Kornasiewicz, Venture Capital w krajach rozwiniętych $i$ w Polsce, Wydawnictwo CeDeWu, Warszawa 2004, p. 22. 
characterized by the financial institutions and large corporations' sector ${ }^{25}$. Lowering the cost of securitization process through changes such as greater availability of credit rating agencies, information standardization, changes in tax and bankruptcy law could contribute to the greater availability of this instrument in the social economy enterprise sector. Importance parts that would have to come together for the real possibility of securitization usability by these players is lowering financial expenditures as a result of the introduction of the single capital market concept, as well as linking it with social entrepreneurship fund activity focused and designed for social enterprise portfolios. Practical functioning of the European Social Entrepreneurship Fund will be of great importance for this to succeed. Due to the specific financing needs of this type of entities, referred to as the qualifying portfolio enterprises, the abovementioned fund distinguishes securitization as one of the main instruments that fall under qualifying investments ${ }^{26}$.

Building capital markets union could also result in corporate bonds liquidity and securitization increase, primarily through greater access to standardized information on the issuer's financial situation through creation of credit rating agencies specialized in this segment of the market, or other mechanisms to ensure analytical assessment of their economic credibility ${ }^{27}$. The emphasis is on the need to develop local credit rating agencies, who are economic condition assessment and evaluation experts of the small-scale production entities ${ }^{28}$. An introduction of mandatory assessment of their economic condition by independent analysts would improve the transparency and credibility of the social corporate bond market or securitized assets, consequently increasing investor base and driving improvement in market liquidity ${ }^{29}$. Growing investor interest in the activities of social enterprises in European Union countries and the local nature of the credit rating agencies, corporate bond market, or the use of securitization may be more accessible to those entities, especially based on the experience of the global financial crisis, in order to eliminate conflicts of interests between the issuer and evaluator, emerges a proposition to cover part of the overall costs incurred by the companies by the evaluators and/or introduction of information-rating system subsidies from the European Union funds.

\section{European information platform}

In the context of the capital availability for social enterprises in the realm of capital market unions, necessary seems a discussion around a construction of a single European information platform containing reports available both in English and the entity's native language published by small businesses. A big role in this regard can also play the SMEs themselves, which, through sharing, and regular and immediate information update contained on their websites would foster building better relationship with investors. There's an emphasis on the possibility of developing general information standards across the European Union at the same time possibly creating dangers in such an approach. Excessive

\footnotetext{
${ }^{25}$ A. Janc, P. Mikołajczak, K. Waliszewski, Europejska Unia Rynków Kapitałowych. Perspektywa finansowania przedsiębiorstw w Polsce, Wydawnictwo CeDeWu, Warszawa 2015, p. 135.

${ }^{26}$ EU Commission, Building a Capital Markets Union, "Green Paper" 52015DC0063 (2016).

${ }^{27}$ V. Bavoso, High Quality Securitisation and EU Capital Markets Union - Is it Possible? Journal of Financial Perspectives, Forthcoming, 2015.

${ }^{28}$ E. Ferran, Understanding the new institutional architecture of EU financial market supervision, "University of Cambridge Faculty of Law Legal Studies" 2011, 29, p. 129-138.

${ }^{29}$ K. Lannoo, Which Union for Europe's Capital Markets, „CEPS/ECMI Policy Brief” 2015, 22.
} 
standardization can be counterproductive, bringing about depletion of the source of information available to investors. For this reason, the greatest emphasis should be placed on the transfer of information allowing for the correct assessment of investment risk. Remaining areas of issuer's activities may instead have a more personalized character. The above made remarks are of particular importance for enterprises, whose mission is inscribed into their operation. The specificity of their operation is focused on solving the most common local or regional problems in their social sphere requiring knowledge of the conditions that shape the environment where they operate, and the specific risks associated with that. The variety and diversity of social problems in various European countries leads to the conclusion that the standardization of information provided to investors will not be appropriate for these types of entities, and pose a risk of distorting the image of their individual operations in the eyes of actual and potential social bond buyers.

With regard to the disclosure obligations, often emphasized is the considerable cost of providing information which lowers operating budget of smaller entities. An important element of lowering the costs associated with reporting would be an introduction of a standard that allows data analysis and comparability preservation. The standard should be compliant with other standards applied by the supervisory authorities of the EU and consider current and future technological capabilities ${ }^{30}$. Also noteworthy are the efforts to facilitate information access about companies/issuers to investors from different countries. A useful tool for such action could be a central information database managed by regional centers. Social enterprises then would have an easier chance of reaching investors.

\section{Social Venture Capital and Social Business Angels}

The proposed regulations related to the concept of the CMU should also have a positive impact on the opportunities for financing social enterprises with venture capital funds, including those social entities with a greater scope of action of social venture capital (SVC) and social business angels (SBA). The consequences of the introduction of the above mentioned changes may be multidimensional. Wider possibilities of social investors exiting the investment through IPO transactions in the unified capital market would allow them a stronger incentive to take risks ${ }^{31}$. IPOs are usually held on the national stock exchanges, where smaller companies tend to favor local exchanges seen in the phenomenon of "home bias" $^{132}$. Investors who tend to have a strong preference to buy shares from their own countries tend to limit investment in non-indigenous capital markets ${ }^{33}$. In addition, SVC funds would gain better, cheaper and wider access to information about the social economy enterprises, which could lead to strengthening of M\&A transactions. Also, social venture capital funds and social business angels would have a greater possibility of raising capital, which probably would result in a more intensified activity in all phases of the social

${ }^{30}$ N. Anderson, M. Brooke, M. Hume, M. Kürtösiova, A European Capital Markets Union: implications for growth and stability, "Bank of England Financial Stability Paper" 2015, 33, p. 3-23.

${ }^{31}$ M. Pagano, A.A. Röell, J. Zechner, The geography of equity listing: why do companies list abroad? „The Journal of Finance” 2002, 57/6, p. 2651-2694.

32 L.L. Tesar, I.M. Werner, Home bias and high turnover, „Journal of international money and finance" 1995, 14/4, p. 467-492.

33 J.K. Kang, Why is there a home bias? An analysis of foreign portfolio equity ownership in Japan, Journal of financial economics" 1997, 46/1, p. 3-28. 
enterprise operation interested in the introduction of social innovation with a wide range of impact.

Important solutions that could be done in terms of direct support for SVC funds in connection with the unification of capital markets are also systemic and equal inclusion of this type of investment entities to the spectrum of available investment instruments market, insurance and pension funds, as well as co-investments with SVC funds powered by public means exclusively based on market principles. An interesting solution encouraging institutional investors, managing SCV high-value long-term asset, as an innovative social investment that would create opportunities and eliminate barriers to investment in these market segments, indirectly through the purchase of holdings in the SVC asset types.

\section{Crowdfunding and Venture Philantrophy}

Crowdfunding can provide many benefits to social enterprises (particularly those who operate locally) manifested in the flexibility of this type of instrument, involvement of local communities and the diverse forms of funding ${ }^{34}$. The European Commission holds an opinion that crowdfunding is an important support for entrepreneurship, including SMEs, artists, innovative start-ups, and social entrepreneurs, who can benefit from various forms of crowdfunding.

The Commission notes, however, numerous challenges facing crowdfunding. Those relate mainly to the lack of transparency of the applicable rules, especially in the area of equity. Although some countries already created sets of regulations or guidelines in this area, the Commission points to the problems and risks that may give rise to a variety of regulatory approaches in different countries. These actions can limit the development of social financing, but too liberal of policies create the occurrence of certain risks to investors and can undermine the faith and confidence of crowdufunding. The European Commission therefore has been collecting information on the attitude of the industry to disclose information and positions of Member Counties to the said regulations. Preliminary results indicate that different national approaches in this regard encourage the crowdfunding run locally, but are not always compatible with each other across borders. Due to the local nature of crowdfunding, should its activity to be included in the EU regulations, will unlikely result in popularization of this type of financing on a larger scale. The comments therefore allow to conclude, that the observations of the Commission will not affect negatively the possibilities of financing social enterprises using crowdfunding with the introduction of uniform rules for its functioning. For this reason, it seems that EU countries should not interfere in the implementation of projects, in which capital is obtained by crowdfunding, but rather limit the possible adjustments to a general Europe-wide level for driving mechanisms of additional protection to foreign investors, giving them the possibility, in case of emergency, to protect their interests by using local legal instruments when investigating their own claims. With regard to the Polish social enterprise sector, greater sense of security in above mentioned funding participants could contribute to their increased interest in investing in the development of collective forms of management.

\footnotetext{
${ }^{34}$ E.R. Mollick, The Dynamics of Crowdfunding: Determinants of Success and Failure, "Journal of Business Venturing” 2014, 29, p. 1-16.
} 


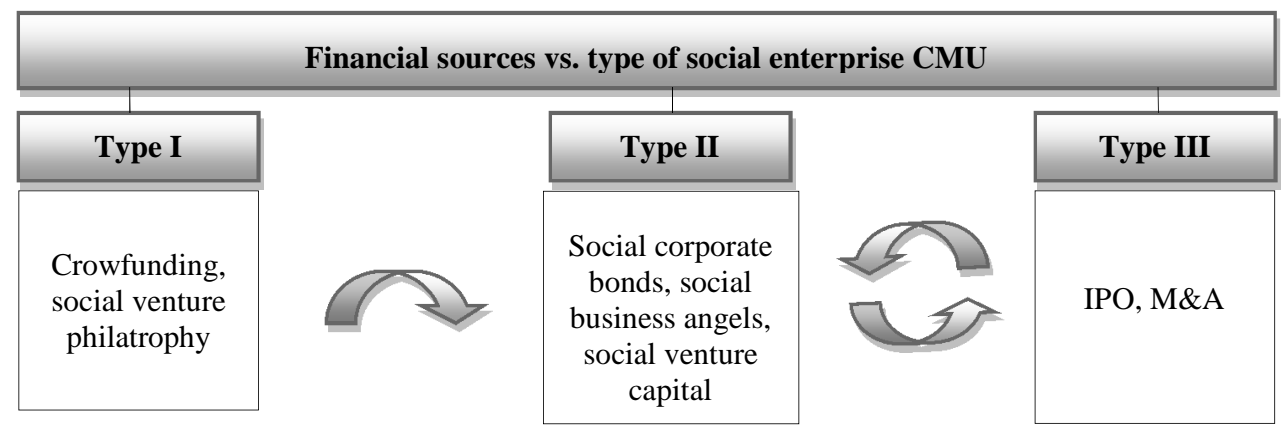

Figure 1. Conceptual model of interaction between social financial sources and type of social enterprises in the context of CMU project

Source: P. Mikołajczak, Źródła i instrumenty.... p. 418.

In addition to promoting the crowdfunding by raising awareness and building trust, significant stimulus that increases the possibility of capital power of social enterprises through crownfunding is the proposal of hybrid funding - public and private, which may be particularly important for these entities. The size of crowndfunding remains limited, and its importance in the scale of the capital market remains marginal ${ }^{35}$. Although it is difficult to expect that crowdfunding will contribute to solving the fundamental problems related to capital access by social enterprises, it appears advisable to provide for the possibility of public funding in conjunction with social capital e.g. venture philatrophy (VP), both at the national and European Union levels. Interference would only be justified in cases where market failure is apparent. This would create a special opportunity for social enterprises, which as previously indicated, experience strong lack of capital. Public aid could take the form, for example, of loan guarantees for transactions on social lending platform or direct social funding, where social entity sector would be separately exposed.

\section{CONCLUSIONS}

In an attempt to assess the impact of the capital markets union's financing opportunities in the social enterprise sector in the light of the earlier made comments, it should be noted that they depend to a large extent on the scale and scope of the social impact of these entities. Small, locally operating companies have a chance to greater access to social financing in the form of crowdfunding. Social enterprises whose scale of the social impact is fairly significant, and the level and scope of social innovation goes beyond local or regional horizons should be the main beneficiaries of the CMU in the entire social enterprise sector. Among all the potential financing sources, outside investors such as social business angels, venture philanthropy, social venture capital funds, should be distinguished above all others. Especially the largest global social businesses should acquire greater access to capital (IPO, M\&A) and thus the chance for development and most significant social impact. The present findings contribute towards understanding at a micro scale how CMU project can translate

${ }^{35}$ EU Commission, The Juncer Comission: a strong and experienced team standing for change, IP/14/984, 10 September 2014. 
into diversification and greater availability of financial sources supporting social entrepreneurs sector. The findings can contribute towards more effective SE funding policy design, as well as more accurate implications forecasting for creating capital market dedicated for these entities. At the same time, social managers operating in social entrepreneurs who have weaker opportunities to gain capital in the comparison with their typically commercial counterparts will find the results useful for developing their business strategies, being more aware of the possible implications of CMU project.

Still, some limitations of the article need to be highlighted. In the context of the CMU tenet we should also emphasize the specificity of the social enterprises themselves, for which profit, although necessary for their proper functioning is not a main focus. Examples of operational activity of such entities suggest reduced profitability compared to their commercial counterparts. Market for social investors, also known as providers of the socalled "patient capital" is still very limited within Europe.

\section{REFERENCES}

1. Abascal M., Alonso T., Pacheco L., First step towards a Capital Market Union, Regulation Flash, 19 February 2015, BBVA Research.

2. Anderson N., Brooke M., Hume M., Kürtösiova M., A European Capital Markets Union: implications for growth and stability, Bank of England Financial Stability Paper, 2015, 33.

3. Battle Anderson B., Dees J.G., Rhetoric, Reality, and Research: Building a Solid Foundation for the Practice of Social Entrepreneurship [In:] Social Entrepreneurship: New Models of Sustainable Social Change, A. Nicholls (eds.), Oxford University Press 2006.

4. Bavoso V., High Quality Securitisation and EU Capital Markets Union - Is it Possible? Journal of Financial Perspectives, Forthcoming 2015.

5. Brinkerhoff D.W., Brinkerhoff J.M., Partnerships between international donors and nongovernmental development organizations: Opportunities and constraints, International Review of Administrative Sciences" 2004, 70/2.

6. Carney M., Gedajlovic E., The co-evolution of institutional environments and organizational strategies: The rise of family business groups in the ASEAN region, Organization Studies, 2002, 23/1.

7. Conner K.R., Prahalad C.K., A resource-based theory of the firm: Knowledge versus opportunism, Organization science, 1996, 7/5.

8. Draghi M., Keynote speech at the Eurofi Financial Forum. Frankfurt am Main: European Central Bank Directorate General Communication 2014.

9. EU Commission, The Juncer Comission: a strong and experienced team standing for change, IP/14/984, 10 September 2014.

10. EU Commission 2015, Building a Capital Markets Union, Green Paper, 52015DC0063.

11. EU Commission 2016, Building a Capital Markets Union, Green Paper, 52015DC0063.

12. Ferran E., Understanding the new institutional architecture of EU financial market supervision, University of Cambridge Faculty of Law Legal Studies, 2011, 29.

13. Fowler A., NGDOs as a moment in history: beyond aid to social entrepreneurship or civic innovation? Third world quarterly, 2000, 21/4.

14. Green Paper, Building a Capital Markets Union, Brussels, COM (2015), 63 final, 7.

15. Groot A., Dankbaar B., Does Social Innovation Require Social Entrepreneurship? Technology Innovation Management Review, 2014, 4/12. 
16. Hamunen M., The Impact of a Capital Markets Union in Europe, CFA Institute Magazine, $2015,26 / 5$.

17. Janc A., Mikołajczak P., Waliszewski K., Europejska Unia Rynków Kapitałowych. Perspektywa finansowania przedsiębiorstw w Polsce, Wydawnictwo CeDeWu, Warszawa 2015.

18. Kang J.K., Why is there a home bias? An analysis of foreign portfolio equity ownership in Japan, "Journal of financial economics" 1997, 46/1.

19. Kaya O., Capital Markets Union: Am ambitious goal but few quick wins, EU Monitor, Deutsche Bank Research, Frankfurt am Main 2015.

20. Kornasiewicz A. (2004): Venture Capital w krajach rozwiniętych i w Polsce, Wydawnictwo CeDeWu, Warszawa 2004.

21. Lannoo K., Which Union for Europe's Capital Markets, CEPS/ECMI Policy Brief, 2015, 22.

22. Marcinkowska M., Wdowiński P., Flejterski S., Bukowski S., Zygierewicz M., Wpływ regulacji sektora bankowego na wzrost gospodarczy-wnioski dla Polski, Inst. Ekonomiczny 2014.

23. Mikołajczak P., The Importance of Funding Sources to the Scale of Activity of Social Enterprises, "Finanse, Rynki Finansowe, Ubezpieczenia" 2017, 4/88.

24. Mikołajczak P., Źródła i instrumenty finansowego wsparcia przedsiębiorstw społecznych, Wydawnictwo UEP, Poznań 2017.

25. Mikołajczak P., Struktura finansowania inwestycji małych i średnich przedsiębiorstw refundowanych z funduszy europejskich $w$ Wielkopolsce, „Humanities and Social Scencies” 2014, 3.

26. Mikołajczak P., Czternasty W., Social enterprises versus globalisation, INTERCATHEDRA, 2015, 31/2.

27. Mollick E.R., The Dynamics of Crowdfunding: Determinants of Success and Failure, "Journal of Business Venturing" 2014, 29.

28. Pagano M., Röell A.A., Zechner J., The geography of equity listing: why do companies list abroad?, "The Journal of Finance" 2002, 57/6.

29. Popov A., Udell G. (2012): Cross-border banking, credit access, and the financial crisis, Journal of International Economics, 87/1.

30. Tesar L.L., Werner I.M., Home bias and high turnover, "Journal of international money and finance" $1995,14 / 4$.

31. Thompson J., Alvy G., Lees A., Social entrepreneurship-a new look at the people and the potential, Management decision, 2000, 38/5.

32. Vacekova G., Valentinov V., Nemec J., Rethinking non-profit commercialization: the case of the Czech Republic, Voluntas, "International Journal of Voluntary and Nonprofit Organizations" 2017, 28/5.

33. Zahara S.A., Gedajlovic E., Neubaum D.O., Shulman J.M., A typology of social entrepreneurs: Motives, search processes and ethical challenges, "Journal of Business Venturing" 2009, 24/5. 


\section{UNIA RYNKÓW KAPITAŁOWYCH UNION: TWORZENIE NOWEJ MOŻLIWOŚCI DLA PRZEDSIĘBIORSTW SPOŁECZNYCH}

Celem pracy jest zbadanie badanych przedsiębiorstw pod kątem wykorzystania planowanych zmian Unii Rynków Kapitałowych, głównie dostępu do instrumentów kapitałowych i dłużnych. Istniejąca luka w kapitale dostępnym dla przedsiębiorstw społecznych wskazuje na znaczne ograniczenia zdolności finansowych sektora bankowego, a autor bada kwestię, jakie potencjalne możliwości rozwoju instrumentów finansowych wspierających sektory przedsiębiorstw społecznych można stworzyć w kontekście ustanowienie URM. W obecnej dyskusji na temat URM wiele miejsca poświęcono jej wpływowi na sektor MŚP. Jednak autor nie podejmuje teoretycznej oceny prawdopodobnych konsekwencji projektu dla przedsiębiorstw społecznych. Analiza dostępnych dokumentów wskazuje, że możliwości finansowania $\mathrm{w}$ sektorze przedsiębiorstw społecznych $\mathrm{w}$ wyniku projektu URK będa zależały od skali i zakresu społecznego wpływu przedsiębiorstw społecznych. Główne implikacje tego artykułu przyczyniają się do zrozumienia, w jaki sposób projekt URK może przełożyć się na dywersyfikację i większą dostępność źródeł finansowych wspierających przedsiębiorstwa społeczne, bardziej skuteczny projekt polityki finansowania przedsiębiorstw społecznych i dokładniejsze prognozowanie implikacji dla tworzenia rynku kapitałowego dedykowanego tym przedsiębiorstwom. Menedżerowie przedsiębiorstw społecznych znajdą wyniki przydatne w opracowywaniu strategii biznesowych, będąc bardziej świadomi możliwych skutków projektu URK.

Słowa kluczowe: unia rynków kapitałowych; przedsiębiorcy społeczni, zaopatrzenie kapitałowe, instrumenty finansowe, inwestorzy społeczni, rynek kapitału społecznego.

DOI: $10.7862 /$ rz.2018.hss.80

Tekst złożono do redakcji: grudzień 2017 r.

Tekst przyjęto do druku: grudzień 2018 r. 
